\title{
Pengaruh Faktor Demografi dan Literasi Keuangan dengan Behavior Finance dalam Pengambilan Keputusan Investasi
}

\author{
Elkunny Dovir Siratan ${ }^{1 *}$, Temy Setiawan ${ }^{2}$ \\ 1,2Universitas Bunda Mulia, Indonesia \\ ${ }^{1}$ elkunny@cbn.net.id, ${ }^{2}$ operasionaltemysetiawan@gmail.com \\ ${ }^{*}$ Penulis Korespondensi
}

\begin{abstract}
The investment decision-making process is influenced by various factors, including financial literacy and demographic factors. This research examines the impact of demographic factors and financial literacy with behavioral finance as a mediation on investment decision making. This research using structural equation model (SEM) analysis. The result shows that demographic factors through gender, age, education, income, occupation and experience have an influence and cause a specific behavior in investment decision making. Then the financial literacy factor has an influence in reducing negative behavior. Likewise, demographic factors and financial literacy with behavioral finance as a mediation on investment decisions have a positive influence. The existence of behavior that is manages with planning, financial literacy support, and demographic factors owned by individual investors will create an opportunity for market momentum. Which help maximize profit, better investment and portfolio performance, avoid risks, better investment decision, and forming trading strategies.
\end{abstract}

Keywords: demographic factor, financial literacy, behavioral finance, investment decision

\begin{abstract}
Abstrak
Proses pengambilan keputusan investasi dipengaruhi oleh berbagai faktor, diantaranya literasi keuangan dan faktor demografi. Penelitian ini akan menguji dampak faktor demografi dan literasi keuangan serta behavioral finance sebagai mediasi dalam pengambilan keputusan investasi. Penelitian ini menggunakan teknik analisis structural equation model (SEM). Hasil penelitian menunjukkan bahwa faktor demografi melalui jenis kelamin, usia, tingkat pendidikan dan pendapatan, okupasi serta tingkat pengalaman memiliki pengaruh dan menimbulkan sebuah perilaku spesifik dalam pengambilan keputusan investasi. Kemudian faktor literasi keuangan memiliki pengaruh dalam mereduksi perilaku yang negatif. Demikian dengan faktor demografi dan literasi keuangan dengan behavioral finance memiliki pengaruh positif terhadap keputusan investasi. Sehingga keberadaan perilaku yang dikelola dengan perencanaan, dukungan literasi keuangan dan faktor demografi yang dimiliki individu investor akan menjadi peluang momentum dalam pasar yang membantu memaksimalkan laba, performa investasi dan portfolio lebih baik, menghindarkan risiko, kualitas pengambilan keputusan, dan membentuk startegi trading.
\end{abstract}

Kata kunci: faktor demografi, literasi keuangan, behavioral finance, keputusan investasi

Cara Mengutip:

Siratan., E. D., \& Setiawan, T. (2021). Pengaruh Faktor Demografi dan Literasi Keuangan. Esensi: Jurnal Bisnis dan Manajemen, 11(2), 237-248. https://doi.org/10.15408/ess.v11i2.23671. 


\section{PENDAHULUAN}

Investasi merupakan pengunaan dana pada aset dengan tujuan memperoleh pendapatan atau penambahan modal yang diikuti atribut yaitu risiko dan waktu, sehingga terdapat bentuk komitmen dan pengorbanan terhadap aset atau dana yang dialokasikan selama periode mendatang dan bersifat tidak pasti (Sarkar \& Sahu, 2018; Jensen \& Jones, 2020). Salah satu investasi yang paling umum dan populer adalah investasi saham. Dengan alasan saham merupakan tanda keikutsertaan atau patrisipasi seseorang (investor) baik individu maupun atas nama badan usaha dalam suatu perusahaan yang dituju. Oleh sebab itu, dengan membeli saham suatu perusahaan maka investor sudah berpatrisipasi dan mendapatkan klaim atas pendapatan dan klaim atas aset perusahaan seperti dividen (Baker dkk., 2020).

Pada kenyataan praktiknya, kegiatan investasi saham tidak berjalan dengan yang diharapkan disebabkan suatu pengambilan keputusan yang dilakukan investor didasari pada masalah ketidakpastian dan situasi pasar yang kompleks berujung mempengaruhi faktor psikolgi seperti pola pikir, persepsi, dan tingkat pengetahuan investor yang berbeda. Faktor diatas mempengaruhi proses pengambilan keputusan investasi dalam bentuk sebuah perilaku (Jensen \& Jones, 2020). Keputusan menurut Kahneman (2011) bahwa erat kaitannya dengan sebuah pertimbangan dan penilaian dari dalam diri manusia secara psikologi dalam membuat keputusan dikarenakan faktor ketidakpastian. Rutten dkk. (2013) dan Chaffin (2018) bahwa sebuah keputusan melihat kepada bagaimana manusia memutuskan pada sebuah narasi (keadaan) didasari pada kognitif (melibatkan daya ingat, perhatian, proses mental, dan kreativitas) yang merupakan bagian dari psikologi manusia.

Baker dkk. (2020) menyatakan bahwa investasi saham sebuah proses mengumpulkan kekayaan jangka panjang yang melibatkan sikap rasional, disiplin dan sistematis dalam mencapai tujuan keuangan. Beberapa perilaku diantaranya seperti investor cenderung mengikuti investor lain (dianggap ahli) maupun rumor terkait saham, rekomendasi dan referensi sekuritas, sosial media, dan forum diskusi, cenderung menahan saham yang rugi dalam waktu lama demi menunda kerugian, terlalu optimis terhadap hasil trading dan percaya bahwa informasi sudah cukup dalam pengambilan keputusan investasinya (Beatrice dkk., 2021; Zahera \& Bansal, 2018). Menurut Baker \& Puttonen (2017) terjadi penyimpangan antara apa yang seharusnya dilakukan investor dengan apa yang dilakukan investor pada kenyataannya (behavior gap hypothesis). Tidak ada strategi yang benar dan mutlak dalam investasi, namun perlu dipelajari agar menumbuhkan pengetahuan dan pengalaman yang menimbulkan peluang untuk kekayaan. Hal ini sebagai upaya menghindarkan risiko maupun kesalahan dari perilaku yang ditimbulkan oleh psikologi investor karena pengambilan keputusan investasi sangat penting dalam mengambarkan keberhasilan investor melakukan investasinya (Baker dkk., 2020; Hsu dkk., 2020).

Salah satu faktor menumbuhkan pengetahuan melalui financial literacy yang menggambarkan tingkat pemahaman dan pengetahuan mengenai konsep dan risiko, termasuk kemampuan, motivasi, dan kepercayaan diri ketika menerapkannya dalam membuat sebuah keputusan dalam konteks keuangan (Garg \& Singh, 2018). Sehingga investor yang terdidik secara keuangan akan terhindar pengambilan risiko dan pemikiran tidak logis; maupun pengetahuan secara keuangan yang mendorong keputusan lebih rasional dan berkualitas 
yang berujung pada performa investasi yang berkelanjutan dan pengambilan keputusan yang menguntungkan (Ahmad \& Shah, 2020).

Soekarno \& Pranoto (2020) mengatakan bahwa literasi keuangan merupakan sekumpulan pengetahuan, kemampuan dan sikap dari patrisipasi individu dan keluarga secara keuangan di tengah lingkungan masyarakat saat ini. Hal ini sejalan dengan Garg \& Singh (2018) mengatakan bahwa literasi keuangan merupakan tingkat pemahaman dan pengetahuan mengenai konsep dan risiko termasuk kemampuan, motivasi, dan kepercayaan diri ketika menerapkannya dalam membuat keputusan dalam konteks keuangan yang berujung pada meningkatkan kesejahteraan secara keuangan dan partisipasi dalam kegiatan ekonomi bagi setiap individu maupun masyarakat. Menurut Garg dan Singh (2018), literasi keuangan memiliki 3 dimensi komprehensif. Pertama, financial knowledge, merupakan dimensi utama dan bahkan dianggap mendasari sinonim dari dalam financial literacy. Kedua, financial Attitude, menggambarkan bagaimana individu menyikapi maupun kecenderungan berperilaku spesifik yang diakibatkan keyakinan ekonomi dan non-ekonomi yang dimiliki individu atas hasil perilaku tertentu. Ketiga, financial behavior, menggambarkan cara individu berperilaku yang mempengaruhi kesejahteraan keuangan secara signifikan.

Rasool dan Ullah (2020) berpendapat bahwa tingkat literasi keuangan yang semakin tinggi dimiliki investor cenderung behavioral bias berkurang. Hal ini sejalan dengan Ozen \& Ersoy (2019) bahwa investor yang tidak mengambil program keuangan perlu meningkatkan pengetahuan (literasi keuangan) demi mencegah pengaruh cognitive biases agar investasi keuangan lebih sesuai. Hal ini didukung oleh Adil dkk. (2021) bahwa semakin tinggi tingkat literasi keuangan cenderung memberikan pengaruh positif dalam kapabilitas baik kaum pria maupun wanita dalam melakukan pengambilan keputusan investasi yang lebih baik.

Cupak dkk. (2020) mengatakan salah satu unsur yang mendukung untuk menumbuhkan rasa kepercayaan diri terkait kepemilikan aset berisiko melalui literasi keuangan. Garg \& Singh (2018) mengatakan tingkat literasi keuangan khususnya financial behavior yang semakin tinggi maka investor cenderung memiliki tingkat keikutsertaan atau komitmen yang tinggi. Hal ini sejalan dengan Rahman dan Gan (2020) bahwa diperlukannya financial knowledge baik fundamental dan technical demi meningkatkan psychological behavior yang mencegah keputusan bersifat irasional maupun keberadaan behavioral biases untuk mereduksi risiko dan meningkatkan perilaku positif dalam investasi.

Kemudian faktor lain yang turut berpengaruh terhadap pengambilan keputusan adalah faktor demografi yang dimiliki setiap investor dan menggambarkan aspek keunikan tersendiri, sehingga setiap investor tidak dapat mengandalkan atau tergantung terhadap pengambilan keputusan yang dilakukan investor lain (Sarkar \& Sahu, 2018). Baker dkk. (2019) faktor demografi dalam perbedaan jenis kelamin (gender) khususnya kaum pria cenderung melakukan overconfidence dan mental accounting. Sedangkan kaum wanita cenderung melakukan disposition effect. Ozen \& Ersoy (2019) juga mengatakan bahwa tingkat pengalaman dipandang sebagai sumber informasi pengetahuan financial dan menimbulkan perbedaan dalam cognitive biases dalam pengambilan keputusan investasinya. Serta Beatrice dkk. (2021) seperti usia, gender, pendidikan, occupation, pendapatan dan pengalaman memiliki dampak berbeda terhadap pembentukan behavioral biases yang mempengaruhi pengambilan keputusan investasi. 
Jenis kelamin (gender) memiliki pengaruh dalam sikap, preferensi, dan pengambilan keputusan terkait risiko (Hsu dkk., 2020). Hsu dkk. (2020) dan Cupak dkk. (2020) memperlihatkan perbedaan jenis kelamin (gender) memiliki pengaruh dalam sikap, preferensi, dan pengambilan keputusan terkait risiko, seperti kaum pria lebih berani ambil risiko dibandingkan kaum wanita cenderung emosional dan risk averse. Sedangkan dari faktor usia Sarkar \& Sahu (2018) menggambarkan bagaimana investor ber-reaksi terhadap perubahan harga pasar saham, volume trading maupun memilih preferensi saham dan melihat trend saham dari masa lalu. perbedaan dalam faktor usia menimbulkan perbedaan dalam pengambilan keputusan. Isidore \& Christie (2019) menjelaskan bahwa dari segi perbedaan tingkat pendapatan akan mempengaruhi bagaimana pola individu mengelola pendapatan secara proposional. Beatrice dkk. (2021) individu yang memiliki pekerjaan pada sektor atau bidang keuangan, akan lebih paham mengenai investasi dan keputusan yang jauh lebih baik. Metawa dkk. (2019) mengatakan semakin tinggi tingkat pengalaman cenderung mengabaikan pengaruh emosi dari sentimen dan membentuk kepribadian investor dalam mengambil keputusan investasi.

Kemudian usia menggambarkan bagaimana investor ber-reaksi terhadap perubahan harga pasar saham, volume perdagangan maupun memilih preferensi saham dan melihat tren saham (Sarkar \& Sahu, 2018; Baker dkk., 2019). Serta tingkat pendidikan erat kaitannya dengan pekerjaan bahwa latar belakang dari sisi pekerjaan bidang keuangan kesehariannya akan lebih mengerti baik secara definisi maupun istilah, sehingga ada pengetahuan yang lebih dan pengambilan keputusan yang lebih baik (Beatrice dkk., 2021; Baker dkk., 2019). Diikuti dengan tingkat pendapatan akan mempengaruhi bagaimana pola individu mengelola pendapatan secara proposional (Isidore \& Christie, 2019). Tingkat pengalaman menggambarkan cara investor menyikapi perubahan harga dalam pasar saham, tingkat kepercayaan diri, dan menimbulkan peluang untuk mereduksi risiko maupun kesalahan dari perilaku sebagai suatu pembelajaran (Baker dkk., 2020). Serta tujuan investasi sebagai pertimbangan latar belakang, motif, dan jangka waktu seorang individu melakukan investasi. Hal ini mempengaruhi pengambilan keputusan dan pola investasi yang dilakukannya (Sarkar \& Sahu, 2018).

Behavioral finance yang menggambarkan pemahaman kedisiplinan ilmu financial dengan menggabungkan konsep psikologi (kognitif dan emosional) dalam melihat respon maupun dampak hasil dari pengambilan keputusan investasi yang dibuat oleh para investor. Dimana membatasi pemikiran investor secara rasional maupun pengambilan keputusan yang bersifat subjektif (Jensen \& Jones, 2020; Ritika \& Kishor, 2020). Dengan kata lain, setiap investor yang berpatrisipasi dalam kegiatan investasi saham selalu memiliki persepsi atau pola pikir dan emosional terutama dalam melakukan pengambilan keputusan dalam bentuk sebuah perilaku yang melekat pada diri investor. Sehingga behavioral finance memperlihatkan suatu kualitas tindakan perilaku dalam keseharian pengambilan keputusan investasi seorang investor dan untuk meghilangkan secara penuh merupakan hal yang mustahil (Zahera \& Bansal, 2018). Sehingga sepintar-pintarnya investor tetap bisa melakukan kesalahan dengan behavioral finance dapat dikatakan menempel seperti bawaan cacat pada setiap individu (Baker \& Puttonen, 2017).

Hal ini didukung oleh Chidambaranathan \& Guha (2020) bahwa faktor behavioral biases selalu ada dalam diri investor dalam pengambilan keputusan. Dikarenakan untuk 
mencapai solusi memuaskan baginya dengan menyederhanakan logika (shortcut) maupun pengalaman Sehingga perilaku yang terbentuk diakibatkan atas pengambilan keputusan yang dibuat didasarkan pada rasionalitas yang terbatas. Baker dkk. (2020) berpendapat bahwa pada saat pengambilan keputusan investasi, maka emosi cenderung menjadi indikasi pembalikan perilaku dari apa yang seharusnya dilakukan investor.

Urgensi dilakukan penelitian ini karena pengambilan keputusan investasi menjadi titik penting bagi keberhasilan investasi seorang investor, sehingga perlu diidentifikasi faktor yang mempengaruhi pengambilan keputusan. Penelitian ini mengambil faktor demografi dan literasi keuangan, serta perilaku yang melekat pada diri investor dan dipengaruhi secara psikologi baik kognitif dan emosional. Hal ini yang menjadi kontribusi utama dalam penelitian ini.

\section{METODE}

Metode penelitian menggunakan metode kuantitatif bersifat deduktif yaitu menguji sebuah teori terhadap topik penelitian yang dilakukan, dimana teori dianggap kumpulan asumsi yang menghasilkan prediksi yang teruji. Kemudian menyimpulkan subjek penelitian atau tempat penelitian dalam penelitian ini adalah para investor yang terdaftar pada pasar modal khususnya pasar saham melalui Bursa Efek Indonesia (BEI). Sedangkan objek penelitian dalam penelitian ini adalah seluruh perilaku maupun persepsi atau pola pikir para investor pada pasar saham.

Skala pengukuran yang digunakan dalam penelitian ini adalah skala likert untuk mengukur sikap, pendapat, dan persepsi seorang atau sekelompok orang tentang fenomena sosial sehingga variabel yang diukur dijabarkan menjadi indikator dan indikator tersebut adalah titik tolak penyusunan item berupa pernyataan atau pertanyaan sebagaimana dijelaskan oleh Sugiyono (2019). Kemudian menggunakan empat gradasi dalam skala likert untuk menghindarkan responden melakukan bias social, dimana situasi untuk menyenangkan interviewer agar responden dianggap penolong dengan memilih jawaban netral atau keraguan (titik tengah).

Sampel dalam penelitian ini adalah investor di pasar modal yang melakukan investasi saham melalui komunitas investor di Pulau Jawa, dikarenakan berdasarkan sebaran demografi investor terpusat di pulau jawa sebesar $70.66 \%$ (3.612.546 juta jiwa investor) berdasarkan hasil laporan Indonesia Central Securities Depository (KSEI) April 2021 melalui sebaran (distribusi) investor pasar saham di Indonesia. Kemudian metode pembentukan sampel didasari pada rumus Yamane, Isaac dan Michael dikutip melalui Sugiyono (2019) sehingga diperoleh sampel sebanyak 400 responden. Sedangkan untuk pengolahan data dan pengujian pengaruh menggunakan AMOS versi 22 dengan analisa structural equation model (SEM).

Secara umum kerangka yang diajukan dalam penelitian ini ditunjukkan pada Gambar 1. Penelitian ini akan melihat faktor demografi dan literasi keuangan dalam mempengaruhi pengambilan keputusan dengan memasukkan behavioral finance sebagai variabel moderasi. 
Gambar 1. Kerangka Pemikiran Pengaruh Faktor Demografi dan Literasi Keuangan dengan Behavioral Finance dalam Pengambilan Keputusan Investasi

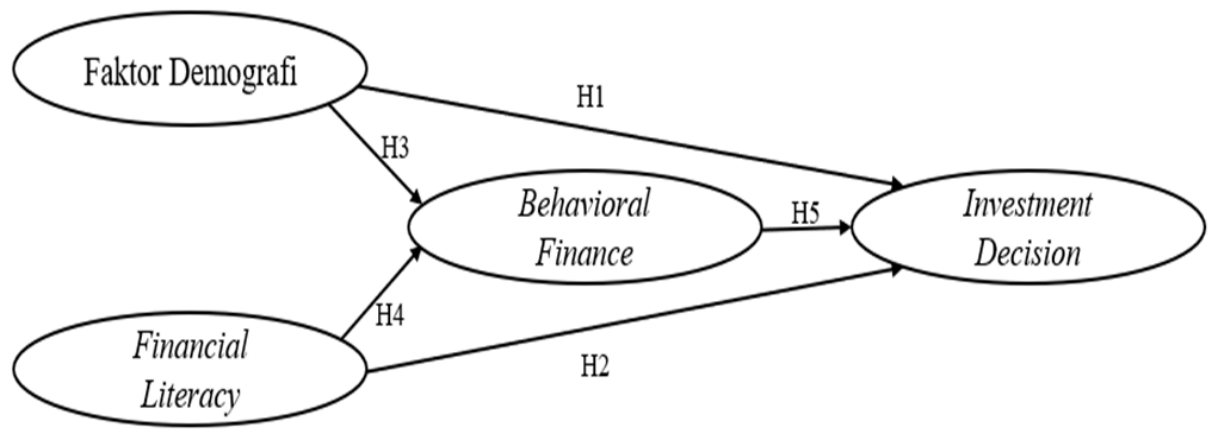

\section{HASIL DAN PEMBAHASAN}

Tabel 1 memperlihatkan bahwa keseluruhan indikator atau butir pertanyaan dalam penelitian dinyatakan valid. Dengan demikian, untuk keseluruhan indikator sudah valid dengan memiliki nilai r-hitung lebih besar dari koefisien korelasi product moment (nilai estimate) yaitu $r$ atau koefisien korelasi product moment (nilai estimate) $>0.40$ (diatas 0.40 ). Hasil ini memperlihatkan bahwa seluruh pertanyaan dalam penelitian ini sudah dinyatakan valid dan dapat dipergunakan dalam proses selanjutnya.

Tabel 1. Hasil Uji Validalitas Penelitian

\begin{tabular}{|c|c|c|c|c|c|}
\hline & & & Estimate & Ketentuan & Keterangan \\
\hline GEN & $<---$ & Demografi & .643 & $>0.40$ & Valid \\
\hline AGE & $<---$ & Demografi & .874 & $>0.40$ & Valid \\
\hline EDU & $<---$ & Demografi & .652 & $>0.40$ & Valid \\
\hline INC & $<---$ & Demografi & .932 & $>0.40$ & Valid \\
\hline EXP & $<---$ & Demografi & .946 & $>0.40$ & Valid \\
\hline FK & $<---$ & Financial & .924 & $>0.40$ & Valid \\
\hline $\mathrm{FB}$ & $<---$ & Financial & .884 & $>0.40$ & Valid \\
\hline FA & $<---$ & Financial & .852 & $>0.40$ & Valid \\
\hline EB & $<---$ & Behavior & .954 & $>0.40$ & Valid \\
\hline BPB & $<---$ & Behavior & .913 & $>0.40$ & Valid \\
\hline RNR & $<---$ & Investment & .853 & $>0.40$ & Valid \\
\hline FUNA & $<---$ & Investment & .824 & $>0.40$ & Valid \\
\hline TENA & $<--$ & Investment & .808 & $>0.40$ & Valid \\
\hline RNR & $<---$ & Investment & .853 & $>0.40$ & Valid \\
\hline
\end{tabular}

Tabel 2 memperlihatkan bahwa keseluruhan indikator atau butir pertanyaan dalam penelitian dinyatakan reliabel. Hal ini dibuktikan sebagaimana penetapan syarat dari Bougie dan Sekaran (2020) dengan ketentuan nilai koefisien alphanya $>0.70$ (diatas 0.70) sudah dapat diterima, sedangkan koefisien alphanya $>0.80$ (diatas 0.80 ) sangat baik. Hasil pada Tabel 2 memperlihatkan bahwa seluruh pertanyaan pada variabel penelitian 
yang digunakan telah reliabel. Sehingga seluruh pertanyaan dapat diproses lebih lanjut dalam penelitian ini.

Tabel 2. Hasil Uji Reliabilitas Penelitian

\begin{tabular}{|c|c|c|c|c|c|c|c|}
\hline $\begin{array}{l}\text { Variabel } \\
\text { Penelitian }\end{array}$ & Indikator & Nilai Valid & Nilai Error & & & & $\begin{array}{c}\text { Nilai } \\
\text { Reliabilitas }\end{array}$ \\
\hline \multirow[t]{3}{*}{ Financial } & FK & 0.924 & 0.515 & $\mathrm{CR}$ & 7.0756 & 7.07 & 0.731990143 \\
\hline & FB & 0.884 & 0.965 & & 2.583 & 9.6586 & \\
\hline & FA & 0.852 & 1.103 & & & & \\
\hline \multirow{5}{*}{ Demografi } & GEN & 0.643 & 0.226 & $\mathrm{CR}$ & 10.067929 & 10.067 & 0.869123863 \\
\hline & AGE & 0.874 & 0.226 & & 1.515 & 11.582929 & \\
\hline & EDU & 0.652 & 1.047 & & & & \\
\hline & INC & 0.932 & 0.129 & & & & \\
\hline & EXP & 0.946 & 0.113 & & & & \\
\hline \multirow[t]{3}{*}{ Behavior } & EB & 0.954 & 1.427 & $\mathrm{CR}$ & 7.890481 & 7.8904 & 0.734778038 \\
\hline & BPB & 0.913 & 0.744 & & 2.848 & 10.738481 & \\
\hline & IPB & 0.942 & 0.677 & & & & \\
\hline \multirow[t]{3}{*}{ Investment } & RNR & 0.853 & 0.697 & $\mathrm{CR}$ & 6.175225 & 6.175 & 0.807060307 \\
\hline & FUNA & 0.824 & 0.364 & & 1.476 & 7.651225 & \\
\hline & TENA & 0.808 & 0.415 & & & & \\
\hline
\end{tabular}

Tabel 3 memberikan gambaran hasil uji goodness of fit terhadap seluruh variabel dalam penelitian. Membuktikan dan memperlihatkan bahwa model yang dibentuk dikatakan sudah fit atau sesuai dengan syarat dan ketentuan yang ditetapkan dalam uji goodness of fit.

Tabel 3. Hasil Uji Goodness of Fit

\begin{tabular}{|c|c|c|c|}
\hline Indikator Goodness of Fit & Syarat atau Ketentuan & Hasil & Keterangan \\
\hline Chi-square $\left(X^{2}\right)$ & Diharapkan kecil & 105.43 & Fit \\
\hline CMIN/DF & $\leq 2$ & 1.545 & Fit \\
\hline RMSEA & $\begin{array}{c}0.05 \leq \text { RMSEA } \leq 0.08 \text { atau rentan nol } \\
\text { hingga mendekati } 1\end{array}$ & 0.37 & Fit \\
\hline GFI & $\geq 0.9$ & 0.963 & Fit \\
\hline AFGI & $\geq 0.9$ atau $0.8 \leq \mathrm{AFGI} \leq 0.9$ & 0.943 & Fit \\
\hline TLI & $\begin{array}{c}0.8 \leq \mathrm{TLI} \leq 0.9 \text { atau rentan nol hingga } \\
\text { mendekati } 1\end{array}$ & 0.969 & Fit \\
\hline $\mathrm{NFI}$ & $\begin{array}{c}0.8 \leq \mathrm{NFI} \leq 0.9 \text { atau rentan nol hingga } \\
\text { mendekati } 1\end{array}$ & 0.938 & Fit \\
\hline PNFI & $\leq 0.9$ & 0.701 & Fit \\
\hline PGFI & $\leq 0.9$ & 0.624 & Fit \\
\hline
\end{tabular}

Tabel 4 Membuktikan dan memperlihatkan bahwa keseluruhan hipotesis berpengaruh dan signifikan. Hal ini dibuktikan sebagaimana penetapan syarat dari Sugiyono (2019) 
dengan tingkat keyakinan 95\% (0.95) sehingga memiliki ketentuan nilai sig $\leq 0.05$ dan nilai critical ratio $\geq 1.96$.

Tabel 4. Hasil Uji Hipotesis Penelitian

\begin{tabular}{lllccccc}
\hline & & & Estimate & S.E. & C.R. & P & Label \\
\hline Behavior & $<---$ & Demografi & .244 & .068 & 3.588 & $\star \star \star$ & par_11 \\
Behavior & $<---$ & Financial & .534 & .248 & 2.153 & $\star \star \star$ & par_14 \\
Investment & $<---$ & Behavior & .541 & .067 & 8.076 & .004 & par_12 \\
Investment & $<---$ & Demografi & .226 & .063 & 3.587 & $\star \star *$ & par_13 \\
Investment & $<---$ & Financial & 1.008 & .332 & 3.039 & .002 & par_15 \\
\hline
\end{tabular}

Setiap dari faktor demografi seperti gender, usia, pendidikan, pendapatan, occupation, dan pengalaman memiliki pengaruh dan pembentukan perilaku (bias) yang spesifik dalam pengambilan keputusan investasi. Faktor demografi khususnya perbedaan jenis kelamin (gender) memiliki pengaruh dalam sikap, preferensi, kepercayaan diri, dan pengambilan keputusan terkait risiko, seperti kaum pria lebih berani memiliki dan ambil risiko dibandingkan kaum wanita cenderung lebih risk averse. Serta perbedaan gender akan membentuk kecenderungan perilaku yang berbeda khususnya overconfidence, illusion of control, dan representative sebagaimana dinyatakan oleh Hsu dkk. (2020), Cupak dkk. (2020), dan Rasool \& Ullah (2020). Sarkar \& Sahu (2018) menjelaskan faktor usia akan menggambarkan bagaimana investor ber-reaksi terhadap perubahan harga pasar saham, volume trading maupun memilih preferensi saham dan melihat trend saham dari masa lalu; serta erat kaitannya dengan loss aversion dan regret aversion. Baker dkk. (2019) dan Beatrice dkk. (2021) berpendapat faktor usia cenderung melakukan anchoring dan disposition effect pada usia muda dibandingkan cenderung melakukan mental accounting pada usia tua.

Ozen \& Ersoy (2019) bahwa individu yang memiliki latar belakang pendidikan financial maupun kehidupan bisnis cenderung lebih mengerti dibandingkan latar belakang pendidikan non-financial. Dengan kata lain, semakin tinggi tingkat latar belakang pendidikan akan menggambarkan pengambilan keputusan investasi yang cenderung rasional karena menghiraukan faktor emosi. Hal ini didukung dalam Baker dkk. (2019) serta Ahmad \& Shah (2020) mengatakan bahwa tingkat pendidikan (education) mempengaruhi kecenderungan overconfidence menjadi positif apabila investor terdidik secara financial, serta menurunkan disposition effect. Baker dkk. (2019) yang mengatakan bahwa occupation cenderung melakukan perilaku (bias) terutama bagi yang tidak bekerja di bidang financial maupun memiliki tingkat edukasi keuangan yang rendah. Hal ini didukung oleh Beatrice dkk. (2021) bahwa occupation cenderung membentuk overconfidence maupun mental accounting disebabkan pengetahuan dalam bidang sehingga lebih percaya diri dalam membuat keputusan maupun pemahaman secara financial yang lebih baik.

Isidore \& Christie (2019) menjelaskan bahwa dari segi perbedaan tingkat pendapatan (income) akan mempengaruhi bagaimana pola individu mengelola pendapatan secara proposional seperti konsumsi, pengeluaran, menabung, dan mengalokasikan aset sebagai modal investasi. Dimana income yang semakin tinggi cenderung menghindarkan disposition 
effect dan membentuk overconfidence karena investor memiliki akses financial advisor yang jauh lebih baik maupun akses mengambil financial literacy. Hal ini didukung Beatrice dll. (2021) dimana income yang tinggi melakukan mental accounting disebabkan kemampuan mengalokasikan investasi secara efisien. Sarkar \& Sahu (2018) mengatakan tingkat pengalaman menggambarkan cara investor keberanian mengambil risiko dan pengambilan keputusan yang agresif karena kemampuan dalam memprediksi pergerakan harga tergantung kepada lamanya tingkat pengalaman investor dalam dunia investasi sebagai suatu pembelajaran. Hal ini dibuktikan melalui Metawa dkk. (2019) bahwa semakin tinggi tingkat pengalaman cenderung mengabaikan pengaruh emosi dari sentimen dan membentuk kepribadian investor dalam mengambil keputusan investasi dalam perilaku diantaranya overconfidence, overreaction maupun underreaction. Serta menurut Beatrice, Murhadi, dan Herlambang (2021) bahwa tingkat pengalaman tinggi cenderung membentuk overconfidence dan menurunkan disposition effect. Dengan alasan pengalaman memberikan suatu pembelajaran dari kesalahan masa lalu untuk berpikir lebih rasional dan pengelolaan portfolio lebih baik.

Cupak dkk. (2020) mengatakan salah satu unsur yang mendukung untuk menumbuhkan rasa kepercayaan diri terkait kepemilikan aset berisiko melalui financial literacy yang dimiliki individu yang menunjukan partisipasi dan keberanian mengambil risiko. Serta Soekarno \& Pranoto (2020) maupun Adil dkk. (2021) mengatakan bahwa financial literacy mampu menghindarkan sikap investor cenderung risk-averse yang tinggi dan cenderung memberikan pengaruh positif dalam kapabilitas baik kaum pria maupun wanita dalam melakukan pengambilan keputusan investasi yang lebih baik. Oleh sebab itu, Ahmad \& Shah (2020) mengatakan bahwa investor yang terdidik secara finansial akan terhindar pengambilan risiko yang berlebihan atau tidak logis; maupun pengetahuan secara finansial yang mendorong keputusan lebih rasional dan kualitas keputusan positif yang berujung pada performa investasi yang berkelanjutan. Sehingga tingkat keputusan investor berdasarkan kemampuan financial dan pengalaman dibandingkan bergantung kepada heuristic atau sentimen investor sendiri yang memiliki tingkat kesalahan yang tinggi tanpa dukungan penyertaan dari financial literacy.

Hsu dkk. (2020) mengatakan diperlukan dukungan financial literacy memberikan dampak secara keseluruhan mengurangi perilaku (bias) dan risiko. Hal ini sejalan dengan Rasool \& Ullah (2020) yang berpendapat bahwa tingkat financial literacy yang semakin tinggi dimiliki investor maka cenderung perilaku berkurang. Hal ini didukung oleh Ozen \& Ersoy (2019) yang mengatakan bahwa tingkat pengalaman dipandang sebagai sumber informasi pengetahuan financial yang erat kaitannya dengan pendidikan dalam menggambarkan tingkat financial literacy yang dimiliki seorang investor dan menimbulkan perbedaan dalam cognitive biases. Seperti conservatism dan framing cenderung terjadi pada investor dengan tingkat literasi keuangan yang rendah atau tidak mengambil pendidikan financial. Hal ini ditambahkan oleh Rahman dan Gan (2020) bahwa diperlukannya financial knowledge baik fundamental dan technical demi meningkatkan psychological behavior yang mencegah keputusan bersifat irasional maupun keberadaan behavioral biases untuk mereduksi risiko dan meningkatkan perilaku positif dalam investasi. Kemudian Baker, Kumar, Goyal, dan Gaur (2019) bahwa financial literacy semakin tinggi cenderung menghindarkan disposition effect namun menaikan kecenderungan mental accounting. Dengan alasan investor yang sudah terdidik secara financial akan memiliki portfolio yang lebih kompleks. 
Jensen \& Jones (2020) berpendapat bahwa keberadaan dan kehadiran dari behavioral finance sebagai kedisiplinan ilmu yang mengamati perilaku investor dalam investasinya ditimbulkan oleh faktor psikologi baik secara kognitif yang berhubungan dengan bagaimana cara manusia berpikir, yang menimbulkan emosi dan perilaku dari para investor sehingga menimbulkan kenyakinan bahwa investor tidak selalu bertindak secara rasional dalam pengambilan keputusan investasi. Hal ini sejalan dengan Ritika \& Kishor (2020) bahwa menggambarkan perilaku investor tidak mencerminkan rasionalitas atau kesalahan psikologi dalam pengambilan keputusan investasi. Hal ini didukung oleh Chidambaranathan \& Guha (2020) bahwa faktor behavioral biases selalu ada dalam diri investor dalam pengambilan keputusan. Dikarenakan untuk mencapai solusi memuaskan baginya dengan menyederhanakan logika (shortcut) maupun pengalaman Sehingga perilaku yang terbentuk diakibatkan atas pengambilan keputusan yang dibuat didasarkan pada rasionalitas yang terbatas. Dengan kata lain sejalan dengan Baker \& Puttonen (2017) bahwa terjadi penyimpangan dalam pengambilan keputusan investasi antara yang seharusnya dilakukan investor dengan kenyataan yang dilakukannya yang dituangkan dalam bentuk perilaku (bias).

Dengan demikian, sepintar-pintarnya investor tetap bisa melakukan kesalahan sehingga behavioral finance dapat dikatakan menempel seperti bawaan cacat pada setiap individu dan untuk meghilangkan secara penuh merupakan hal yang mustahil sebagaimana pernyataan Zahera \& Bansal (2018). Hal ini terus menerus terjadi disebabkan setiap kegiatan investasi akan berujung kepada pengambilan keputusan investasi (investment decision) dan proses yang berkesinambungan (on-going process) sebagaimana disampaikan oleh Jensen \& Jones (2020) maupun Jannah \& Ady (2017). Serta makna dari suatu keputusan dimana erat kaitannya dengan sebuah pertimbangan dan penilaian dari dalam diri manusia secara psikologi dalam membuat keputusan dikarenakan faktor ketidakpastian. Serta melihat kepada bagaimana manusia memutuskan pada sebuah narasi (keadaan) didasari pada kognitif (melibatkan daya ingat, perhatian, proses mental, dan kreativitas) yang merupakan bagian dari psikologi manusia. Sehingga memberikan motivasi kepada manusia dalam pengambilan keputusan yang didasarkan narasi dan psikologi yang menjadi alasan terbaik bagi manusia tersebut dalam bentuk sebuah perilaku sebagaimana dikatakan oleh Kahneman (2011), Rutten dkk. (2013) maupun Chaffin (2018).

\section{SIMPULAN}

Faktor demografi memiliki aspek keunikan yang menggambarkan kondisi sosio-ekonomi investor yang menimbulkan perilaku Sehingga setiap investor tidak dapat mengandalkan atau bergantung terhadap keputusan yang dilakukan investor lain. Gender, usia, pendidikan, occupation, pendapatan, dan pengalaman menjadi faktor dominan membentuk sebuah perilaku investor dalam performa maupun pengambilan keputusan investasi. Literasi keuangan menjadi faktor pendukung bagi investor dalam mereduksi perilaku, menghindarkan risiko dan emosional, menggambarkan kemampuan, kepercayaan diri, motivasi, dan tingkat keikutsertaan (partisipasi) investor maupun pengambilan keputusan yang cenderung rasional dan merubah perilaku investor menjadi lebih positif, kelak menghasilkan pengambilan keputusan yang berkualitas.

Keberadaan perilaku (bias) yang dikelola dengan perencanaan, dukungan literasi keuangan dan faktor demografi yang dimiliki individu investor akan menjadi peluang momentum dalam 
pasar. Sehingga para investor harus memahami perilaku (bias) psikologi yang melekat dalam dirinya pada saat pengambilan keputusan yang membantu memaksimalkan laba, performa investasi dan portfolio lebih baik, menghindarkan risiko, kualitas pengambilan keputusan, dan membentuk startegi trading.

\section{PUSTAKA ACUAN}

Adil, M., Singh, Y. dan Ansari, M.S. (2021). How Financial Literacy Moderate the Association Between Behavioral Biases and Investment Decision? Asian Journal of Accounting, Inpress. https://doi.org/10.1108/AJAR-09-2020-0086.

Ahmad, M. \& Shah, S.Z.A. (2020). Overconfidence Heuristic-Driven Bias in Investment DecisionMaking and Performance: Mediating Effects of Risk Perception and Moderating Effects of Financial Literacy. Journal of Economic and Administrative Science, In-press. https:// doi.org/10.1108/JEAS-07-2020-0116

Baker, H.K., Kumar, S., Goyal, N. \& Gaur, V. (2019). How Financial Literacy and Demographic Variables Relate to Behavioral Biases. Managerial Finance, 45(1), 124-146. https://doi. org/10.1108/MF-01-2018-0003

Baker, H.K., Nofsinger, J.R. dan Spieler, A.C. (2020). The Savvy Investor Guide to Building Wealth Through Traditional Investment. Emerald Publishing Limited, United States.

Baker, H.K., \& Puttonen, V. (2017). Investment Traps Exposed. Emerald Publishing Limited, United Kingdom. https://doi.org/10.1108/978-1-78714-252-720171004

Beatrice, V., Murhadi, W. R., \& Herlambang, A. (2021). The Effect of Demographic Factors on Behavioral Biases. Jurnal Siasat Bisnis, 25(1), 17-29. https://doi.org/10.20885/jsb. vol25.iss1.art2

Bougie, R., \& Sekaran, U. (2020). Research Methods for Business a Skill Building Approach Eight Edition. Wiley, United States.

Chaffin, C. R. (2018). Client Psychology First Edition. Wiley, New Jersey.

Chidambaranathan, M., \& Guha, S. (2020). Can behavioral Biases Improve the Financial Capability of Microfinance Clients in the Tribal State of India? Strategic Change, 29(5), 589-606. https://doi.org/10.1002/jsc.2367

Cupak, A., Fessler, P., \& Schneebaum, A. (2020). Gender Differences in Risky Asset Behavior: The Importance of Self-Confidence and Financial Literacy. Finance Research Letter, 42, 101880. https://doi.org/10.1016/j.frl.2020.101880.

Garg, N., \& Singh, S. (2018). Financial Literacy Among Youth. International Journal of Economics, 45(1), 173-186. https://doi.org/10.1108/IJSE-11-2016-0303

Hsu, Y. L., Chen, H. L., Huang, P. K., \& Lin, W. Y. (2020). Does Financial Literacy Mitigate Gender Differences in Investment Behavioral Bias? Finance Research Letter, 41, 101789. https://doi.org/10.1016/j.frl.2020.101789.

Isidore, R. R., \& Christie, P. (2019). The Relationship Between the Income and Behavioral Biases" Journal of Economic and Administrative Science, 24(47), 127-144. https://doi. org/10.1108/JEFAS-10-2018-0111

Jannah, W., \& Ady, S. U. (2017). Analisis Fundamental, Suku Bunga, dan Overconfidence 
Terhadap Pengambilan Keputusan Investasi Pada Investor di Surabaya. Jurnal Bisnis dan Manajemen, 1(2), 138-155. https://doi.org/10.25139/ekt.v0i0.338.

Jensen, G. R., \& Jones, C. P. (2020). Investment Analysis and Management Fourteenth Edition. Wiley, United States.

Kahneman, D. (2011). Thinking Fast and Slow. Farrar, Straus and Giroux, New York.

Metawa, N., Hassan, M. K., Metawa, S., \& Safa, M. F. (2019). Impact of Behavioral Factors on Investors' Financial Decisions: Case of the Egyptian Stock Market. International Journal of Islamic and Middle Eastern Finance and Management, 12(1), https://doi. org/10.1108/IMEFM-12-2017-0333

Ozen, E., \& Ersoy, G. (2019). The Impact of Financial Literacy on Cognitive Biases of Individual Investors. Contemporary Issues in Behavioral Finance (Contemporary Studies in Economic and Financial Analysis), 101, 77-95. https://doi.org/10.1108/S1569-375920190000101007

Rahman, M., \& Gan, S. S. (2020). Generation Y Investment Decision: An Analysis using Behavioral Factors" Managerial Finance, Vol. 46, No. 8, pp. 1023-1041. https://doi. org/10.1108/MF-10-2018-0534

Rasool, N. dan Ullah, S. (2020). Financial Literacy and Behavioral Biases of Individual Investors: Empirical Evidence of Pakistan Stock Exchange. Journal of Economic, Finance, and Administrative Science, 25(50), 261-278. https://doi.org/10.1108/JEFAS-03-2019-0031

Ritika., \& Kishor, N. (2020). Development and Validation of Behavioral Biases Scale: a SEM Approach. Review of Behavioral Finance, In-press. https://doi.org/10.1108/RBF-052020-0087

Rutten, M .E .J., Doree, A. G., \& Halman, J. I. M. (2013). Exploring the Value of a Novel Decision-Making Theory in Understanding R\&D Progress Decisions. Management Decision, 51(1), 184-199. https://doi.org/10.1108/00251741311291382.

Sarkar, A.K. dan Sahu, T.N. (2018). Investment Behavior Towards an Individual-Centered Financial Policy in Developing Economies. Emerald Group Publishing, United Kingdom.

Soekarno, S., \& Pranoto, S. (2020). Influence of financial literacy on the stock market participation and financial behavioral among Indonesian Millennials. Advanced Issues in the Economics of Emerging Markets (International Symposia in Economic Theory and Econometrics), 27, 115-125. https://doi.org/10.1108/S1571-038620200000027009.

Sugiyono. (2019). Metode Penelitian Kuantitatif Kualitatif dan R\&D. Alfabeta, Bandung.

Zahera, S. A., \& Bansal, R. (2018). Do Investors Exhibit Behavioral Biases in Investment Decision Making? A Systematic Review. Qualitative Research in Financial Markets, 10, (2), 210-251. https://doi.org/10.1108/QRFM-04-2017-0028. 